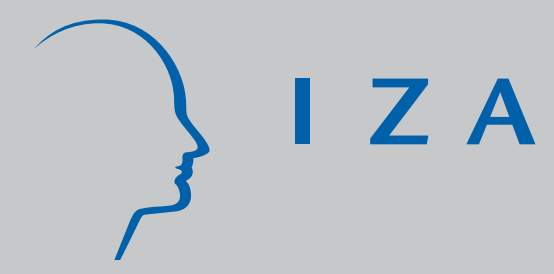

IZA DP No. 3097

Africa's Education Enigma? The Nigerian Story

Ruth Uwaifo Oyelere

October 2007 


\title{
Africa's Education Enigma? The Nigerian Story
}

\author{
Ruth Uwaifo Oyelere \\ Georgia Institute of Technology \\ and IZA
}

\section{Discussion Paper No. 3097 \\ October 2007}

\author{
IZA \\ P.O. Box 7240 \\ 53072 Bonn \\ Germany \\ Phone: +49-228-3894-0 \\ Fax: +49-228-3894-180 \\ E-mail: iza@iza.org
}

\begin{abstract}
Any opinions expressed here are those of the author(s) and not those of the institute. Research disseminated by IZA may include views on policy, but the institute itself takes no institutional policy positions.

The Institute for the Study of Labor (IZA) in Bonn is a local and virtual international research center and a place of communication between science, politics and business. IZA is an independent nonprofit company supported by Deutsche Post World Net. The center is associated with the University of Bonn and offers a stimulating research environment through its research networks, research support, and visitors and doctoral programs. IZA engages in (i) original and internationally competitive research in all fields of labor economics, (ii) development of policy concepts, and (iii) dissemination of research results and concepts to the interested public.
\end{abstract}

IZA Discussion Papers often represent preliminary work and are circulated to encourage discussion. Citation of such a paper should account for its provisional character. A revised version may be available directly from the author. 
IZA Discussion Paper No. 3097

October 2007

\section{ABSTRACT}

\section{Africa's Education Enigma? The Nigerian Story}

In the last two decades, the social and economic benefits of formal education in Sub-Saharan Africa have been debated. Anecdotal evidence points to low returns to education in Africa. Unfortunately, there is limited econometric evidence to support these claims at the micro level. In this study, I focus on Nigeria a country that holds $1 / 5$ of Africa's population. I use instruments based on the exogenous timing of the implementation and withdrawal of free primary education across regions in this country to consistently estimate the returns to education in the late 1990s. The results show the average returns to education are particularly low in the $90 \mathrm{~s}$, in contrast to conventional wisdom for developing countries $(2.8 \%$ for every extra year of schooling between 1997 and 1999). Surprisingly, I find no significant differences between OLS and IV estimates of returns to education when necessary controls are included in the wage equation. The low returns to education results shed new light on both the changes in demand for education in Nigeria and the increased emigration rates from African countries that characterized the 90 s.

JEL Classification: J24, I21, I29, O12

Keywords: human capital, instrumental variables, Nigeria, returns to education, schooling

Corresponding author:

Ruth Uwaifo Oyelere

School of Economics

Georgia Institute of Technology

781 Marietta Street

Atlanta Georgia, 30318

USA

E-mail: ruth.uwaifo@econ.gatech.edu 


\section{Introduction}

Over the last three decades, questions have been raised on why many developing countries are not experiencing significant growth and development especially in Sub-Saharan Africa. Explanations have included a combination of poor technology, bad governments, extractive institutions, weak policy choices, health crises and poor education (see Easterly, 2001). In the last ten years several authors have considered these hypotheses regarding lack of growth in several African countries. The education sector has been examined extensively, but one important question, the return to education, is still unresolved.

In the $80 \mathrm{~s}$, attempts were made to estimate returns to education in both developed and developing countries. Nonetheless, the econometric techniques used in these estimations were prone to bias because of measurement error and unobservables correlated with schooling. With the development of new econometric techniques early in the 90s to deal with these problems, there has been a resurgence of interest in the estimation of returns to education in other parts of the world. However, most of the recent studies on Africa have not made use of these new econometric techniques, for lack of appropriate instruments. Hence, estimates for return to schooling were still derived using ordinary least squares (OLS). ${ }^{1}$ As the endogenous nature of schooling is not addressed with the OLS estimator, the estimated returns to education could be biased. Consequently, there is still room for improvement in estimating returns to education in Africa.

In this paper, returns to education are estimated using the instrumental variable approach. I consider the most populous country in Africa, Nigeria. The Nigerian case is especially interesting because of its importance in Africa in terms of population size (one out every five Africans is Nigerian), diversity (one of the

\footnotetext{
${ }^{1}$ Relevant papers are highlighted in the literature review.
} 
most ethnically diverse with over 354 languages), and key position in oil and gas production in Africa. As with some other African countries, the role and importance of formal education in Nigeria have been debated since the economic downturn in the early $80 \mathrm{~s}$. This controversy was linked primarily to the lack of significant growth in the economy over the 80 s and 90 s, despite the massive increase in human capital investment via education in the 1960's and 1970's. Also contributing to this controversy was the fall in living standards and real income of many well-educated Nigerians between 1983 and 1998, relative to some of their uneducated counterparts. This situation has raised many unanswered questions about the private and social value of education in Nigeria. One of these questions will be addressed in this paper.

The research question I consider is what were the returns to education in Nigeria? The goal here is to consistently estimate the returns to education as revealed in income late in the 90 s in Nigeria. ${ }^{2}$ The answer should not only provide estimates of the average returns to education in an African country where the economic value of education is the subject of debate, but can also help us evaluate the extent of bias of ordinary least squares estimates of returns to education in the Nigerian case.

The returns to education are estimated in this paper using two stage least squares (2SLS). The instrument used in this analysis is based on a free primary education program called Universal Primary Education (UPE), designed to increase educational attainment, exploiting differences in the periods of implementation of this program across states/regions over time in Nigeria, along the lines of the approach used in Duflo (2001).

The instrument can be constructed in different ways. I construct the instrument as the length of exposure to free education. The argument here is the longer

\footnotetext{
${ }^{2}$ In this paper, private return to education is simply referred to as return to education.
} 
an individual is exposed to free education, the higher the school attainment.

To highlight the importance of including appropriate controls in the estimation, the 2SLS estimation of returns to education was carried out, both with and without additional variables. Furthermore, as a benchmark to compare these estimates, the OLS technique is also used to estimate the returns to education. Using these techniques, I estimate a $2.8 \%$ increase in income for every extra year of schooling in Nigeria between 1997-1999. This estimate of return to education is low and far from what the conventional wisdom expects for a developing country in terms of returns to education. Furthermore, this estimate is much lower than other estimates in other Sub-Saharan countries. The review of Psacharopoulos and Patrinos (2004) reports average returns to education in Africa of $11.7 \% .^{3}$.

Several robustness checks were carried out including correcting for potential sources of selectivity and the above results still hold. Surprisingly, I find that OLS estimates of returns to education are slightly lower than IV estimates but not significantly different. Finally, I find that omitting important control variables from the wage equation can bias returns to education estimates significantly.

The present study therefore provides the first estimates of returns to education, using a credible instrument, in a West African country. Furthermore, the results provides reliably evidence of low returns to education in Africa. This result is important since low returns can lead to a fall in the demand for education over time. A fall in education investment could be a problem if education investment has large externalities or social returns despite low private returns. Furthermore, this paper draws attention to the importance of including controls in the estimation of returns to education. Finally, several explanations have been sought for

\footnotetext{
${ }^{3}$ Also, see Schultz (2004) for a review on estimates for selected African countries. It should be mentioned that my estimates are not directly comparable to some of the studies highlighted in Schultz (2004), which estimate returns at each level of education.
} 
the changing demand for education and increased emigration rates in the $90 \mathrm{~s}$ in Africa. The low returns to education in Nigeria suggests one possible explanation for these phenomena.

The remainder of this paper is organized as follows: In the next section, I review previous studies and provide a general background. Section 3 highlights the empirical and identification strategies and Section 4 presents the data. Section 5 presents the results and the last section provides implications and concluding remarks.

\section{Previous Studies and General Background}

\subsection{Literature Review}

From the 1950s, different models have been proposed and tested to evaluate the hypothesis that education affects earnings. Though this relationship has been explored in different ways, recently, schooling and its relationship to wage deter-

mination have most often been analyzed in the framework of Mincer (1974) wage equation. Over the years, several authors have noted various flaws to this human capital approach. These flaws include omitted variables in the estimation equation, and problems of endogeneity of the education coefficient.

Adjustments have been suggested to the earnings function in order to deal with the problems stated above. Much of the schooling literature, starting from the late 70 s, focuses on disentangling education's independent effect on wages. Examples of papers attempting to do this using different techniques are Griliches (1977), Angrist and Krueger (1991), Ashenfelter and Rouse (1998), Harmon and Walker (1995), Card (1999) and Duflo (2001). The most commonly used new technique relies on finding instrumental variables (IV) to correct for the endogenous nature of schooling. 
Most of the studies using an IV strategy to properly estimate returns to education have focused on developed countries. Studies using the IV approach are less common for developing countries (see Psacharopoulos and Patrinos (2004) and Card (1999)). The best known paper using the IV technique in a developing country is Duflo (2001) on Indonesia. Since this paper, other attempts have been made in developing countries but there has been little progress considering African countries (see Glewwe (2002) for a review of related literature for developing countries).

Up to now, most authors estimating the returns to education in Africa have relied on methods of estimation that do not adequately deal with the endogenous nature of schooling. Hence, estimates of returns to education could be biased. Some researchers simply estimated average returns and returns at each level of education using the OLS framework. ${ }^{4}$ Examples of such papers are Mwabu and Schultz (1996) for South Africa, Hovey et al (1992) for Kenya, Aromolaran (2004) for Nigeria. Other authors maintain the OLS framework but go a step further to account for the endogenous choice of sector of employment, correct for selectivity and control for omitted variables like ability. ${ }^{5}$ Also, some of these authors like Glewwe (1996) make use of alternate estimators like maximum likelihood estimator (MLE) all in an attempt to improve estimates. However, even with these improvements, estimates of returns could still be biased due to reasons highlighted above.

Yet another approach to the returns to education estimation with some examples for African countries involves estimating returns based on surveys of em-

\footnotetext{
${ }^{4}$ It is possible OLS might not be biased in some cases. As Griliches (1977) noted, unobservable and measurement biases may actually cancel out leaving the OLS estimates very close to the true return to education.

${ }^{5}$ See for example Kazianga (2002) for Burkina Faso, Glewwe (1996) for private and government sector workers in Ghana, Siphambe (2000) for Botswana, Nielsen and Westergard-Nielsen (2001) for Zambia and more recently Lassibille and Tan (2005) for Rwanda.
} 
ployees in firms rather than households. (See for example Jones (2001)for Ghana, Tekaligne (1997) for Zimbabwe, and Kahyarara et al (2004) for Kenya and Tanzania.) As noted in Psacharopoulos and Patrinos (2004), this methodology is problematic, as ideally a rate of return to investment in education should be based on a representative sample of the countrys population not a minuscule group of workers with formal sector jobs. Firm-based employees are likely to be highly selective.

The only known papers prior to this, using the instrumental variable approach to estimate education returns on data from Sub-Saharan countries, are Kahyarara et al (2004) for Kenya and Tanzania and Dabalen (1998) for Kenya and South Africa. Both papers make use of instruments such as distance to school and parents education. However, results could still be biased because of common issues with the exogeneity of some of the instruments used. For example, parents education may not satisfy exclusion restrictions and distance to schooling may not be exogenous because families with a preference for schooling may choose to migrate closer to a school. In addition, Dabalen (1998) dataset for South Africa had some measurement problems, which he noted could potentially affect his estimates.

As with Dabalen (1998), many papers using the instrumental variable (IV) approach have been critiqued. Staiger and Stock (1997) argued that many studies using IV have weak instruments which led to even more biased estimates of returns to education. Carneiro (2002) argued along similar lines, stating that most of these instruments are correlated with unobservables such as ability, and hence lead to inconsistent estimates of returns to education. Given the importance of the returns to education question for Africa and the limitations of the present studies on African countries highlighted above, there is need for improvement. This is the focus of this paper. 


\subsection{History and Impact of UPE}

As precise identification and estimation of the returns to schooling depends on the instrument, it is important to clearly explain the background for the instrument used to address the endogeneity of schooling. The instrument used in this paper is length of exposure to free education in Nigeria. The idea of using exposure to the UPE as an instrument originated from the paper of Osili and Long (2003) on the impact of education on fertility in Nigeria. Using a difference in difference approach similar to Duflo (2001), Osili and Long (2003) identify a clearly significant impact of the program on primary school attainment for women, over the period of its implementation across regions.

The UPE was a nation-wide program designed to increase educational attainment by providing tuition-free primary education with different periods of implementation across states/regions. This program was first initiated during the colonial period in Nigeria. At this time, Nigeria was divided into four regions, the Northern, Western, Eastern and the federal capital, Lagos. The first region to implement free primary education was the former Western region. The regional implementation of this program was not linked to this region's riches or being most favorable toward more education, but determined by a choice of policy by

the regions' colonial officer in charge of education. This officer believed strongly that free education was the only way the Western region could catch up to the Western world. It is also noted historically, that he convinced the regional leader of the West to implement the program. Hence, the policy reflected his own preference and not the preference of the populace of the region as in a democracy (see Fafunwa (1974) and Adesina (1988) for the history of education in Nigeria).

The program started on the 17th January 1955. In January 1957, the Lagos region that used to be the capital region of the federation initiated the program. 


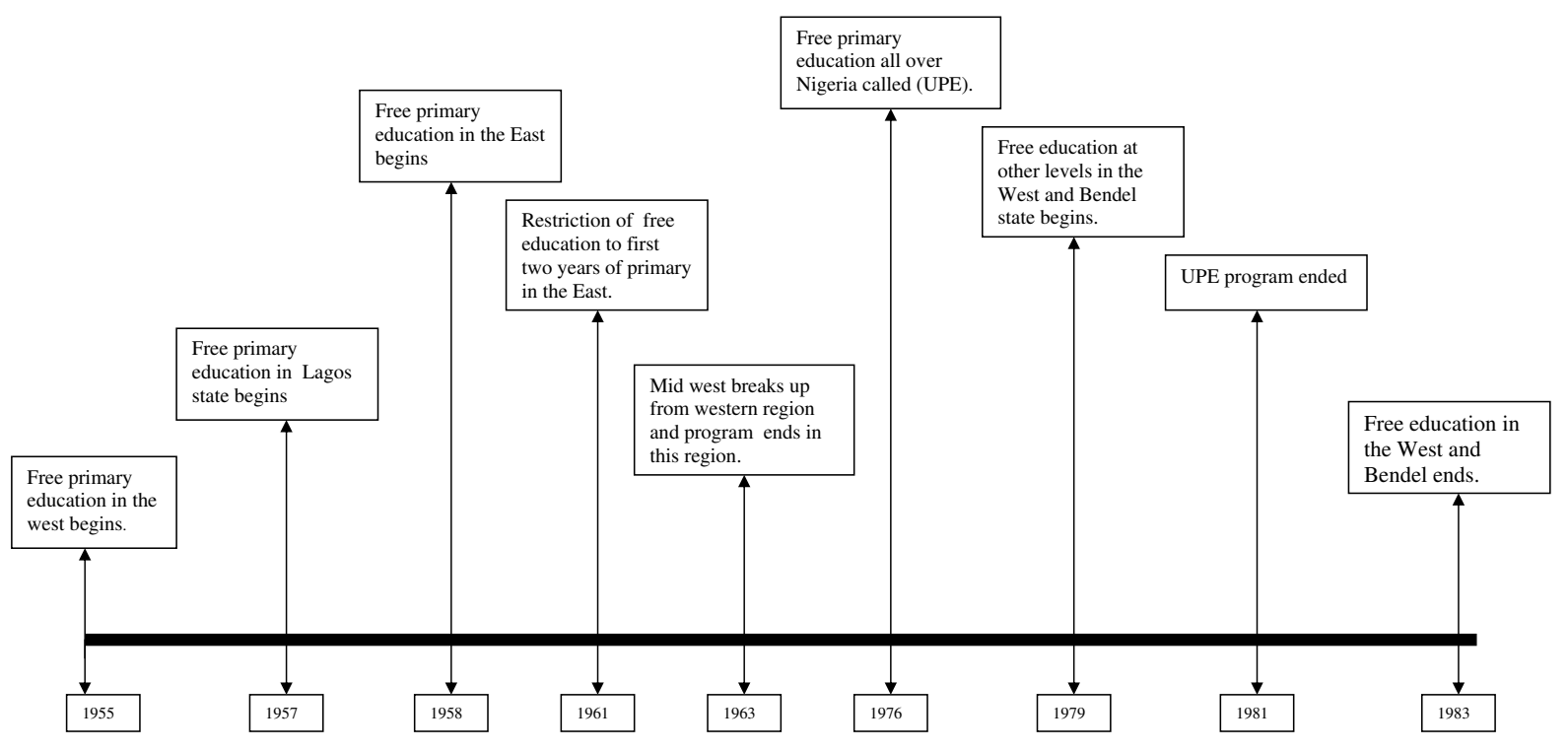

Figure 1: Timeline of Free Education in Nigeria

Subsequently, in February 1957, the regional government of the Eastern region also started the program. Hence at this time, the only region not involved in the program was the North.

However by 1960, the Eastern region had restricted the free education program to only the first two years of primary school. In 1963, Nigeria became a republic and in the same year, the Mid-Western region was carved out of the Western region and was no longer part of the free education policy of the Western region. On the 6th of September 1976 the head of state (Nigeria was under military rule during this period) launched the mandatory program for the whole country, formally naming it UPE. ${ }^{6}$

\footnotetext{
${ }^{6}$ In this paper the instrument will be called UPE.
} 
The program came to an end in 1981 during the first civilian government when the responsibility of education financing moved from the federal government to the state. However, for the duration of the civilian regime (1979-1983) free education was extended to other levels of education in states won by the United Party of Nigeria (UPN) in the 1979 gubernatorial election. ${ }^{7}$ Figure 1 is a timeline of program implementation in Nigeria.

\subsection{Why the UPE makes a Good Instrument}

Does the program constitute a good instrument? We know that any good instrument must satisfy three characteristics.

First, a good instrument must be relevant. The relevance/importance of the free primary education program for school attainment and education development in Nigeria has been documented extensively by several authors. For example, Nwachukwu (1985), Casapo (1983) and Osili and Long (2003) successfully highlight the impact of the UPE program on school attainment. Other descriptive data point to the impact of the program. For instance, by 1947 the Eastern region of Nigeria had the highest primary enrollment of 320,000, followed by the West at 240,000 and the North 66,000. Between 1947 and 1957, there was 212\% increase in primary enrollment in North, 278\% in the East and a 309\% increase in the West. The faster growth in enrollment in the West, even though population growth was similar across the regions, has been attributed to this program. More specifically, the rise in primary enrollment from 475,000 in 1954 in the Western region to 800,000 by 1956 one year after the program's implementation, is attributed to introduction of UPE.

In the 70s, the rise in primary enrollment from 4.4 million in 1974 to 14.5 mil-

\footnotetext{
${ }^{7}$ These states include all the states in the Western regions and also Bendel state from the South-South region which is presently divided into Edo and Delta.
} 
lion by early 1982 was attributed to the reintroduction of the program. Specifically, there was a $124 \%$ increase in primary enrollment from 1975-76 when to program was implemented to $1980-81$, in contrast to an increase of only $4.5 \%$ from 1980 81 to 1984 when the program ended. Given that the Northern regions had not experienced free education prior to the 1976 countrywide implementation of the program, one would expect the intensity of the enrollment effect to be stronger in the North in comparison to the South. This is what we observe historically. The Northern share of total children in primary school in Nigeria jumped from $28.7 \%$ to $46.2 \%$ between 1976 and 1981 . Interestingly, post the program withdrawal this share fell to $42.4 \%$ by 1985 . Also, primary enrollment in the North rose by $63 \%$ between 1976 and 1981 compared to an only 23\% increase in the South where exposure to free primary education had started since the 1950s. This evidence provides further support for the relevance of this program, especially as growth of the population of school age children was quite steady over this period (1960-1980) similarly in all regions. ${ }^{8}$ In addition, a possible argument that the significant jump in enrollment in the mid 70s was caused by the oil boom in the 70s is not valid. This is because the oil boom started in the early 70 s and the significant rise in enrollment was in the mid 70s, coinciding with the implementation of the program nationwide.

Apart from this descriptive evidence, using a difference in differences approach similar to Table 3 on pp798 in Duflo (2001), Osili and Long (2003) identify a significant causal impact of the program on primary school attainment for girls over the period of its implementation (see Table 3 of Osili and Long (2003)). To validate the results of Osili and Long (2003), I also conduct a simple experiment similar to the first half of Table 3 in Duflo (2001) (see Table 1). In contrast to Osili

\footnotetext{
${ }^{8}$ The statistics branch of the Federal Ministry of Education, Victoria Island Lagos is the source of the data information highlighted in this section.
} 
and Long (2003), I focus on both gender. ${ }^{9}$ The findings in Osili and Long (2003)

and Table 1 provide some suggestive evidence that the difference in differences are not driven by inappropriate identification assumptions.

Table 1: Mean of Education in a High vs Low Intensity Region

\begin{tabular}{|c|c|c|c|c|c|c|c|}
\hline & \multicolumn{7}{|c|}{ Year of Education } \\
\hline & High & Low & Difference & & High & $\overline{\text { Low }}$ & Difference \\
\hline & (1) & $(2)$ & $(3)$ & & (1) & $(2)$ & $(3)$ \\
\hline$\overline{P a n e l ~ A}$ & & & & Panel B & & & \\
\hline Aged 2 to 7 in 1976 & $\begin{array}{c}9.97 \\
(0.12)\end{array}$ & $\begin{array}{c}10.5 \\
(0.11)\end{array}$ & $\begin{array}{c}-0.53 \\
(0.18)\end{array}$ & Aged $12-18$ in 1976 & $\begin{array}{c}7.5 \\
(0.098)\end{array}$ & $\begin{array}{c}8.41 \\
(0.11)\end{array}$ & $\begin{array}{c}-0.91 \\
(0.14)\end{array}$ \\
\hline Aged $12-18$ in 1976 & $\begin{array}{c}7.53 \\
(0.101)\end{array}$ & $\begin{array}{c}8.41 \\
(0.11)\end{array}$ & $\begin{array}{l}-0.88 \\
(0.14)\end{array}$ & Aged 19-26 in 1976 & $\begin{array}{c}6.42 \\
(0.116)\end{array}$ & $\begin{array}{c}7.19 \\
(0.14)\end{array}$ & $\begin{array}{c}-0.77 \\
(0.18)\end{array}$ \\
\hline Difference & 2.44 & 2.09 & $\begin{array}{c}0.35 \\
(0.23)\end{array}$ & Difference & 1.08 & 1.22 & $\begin{array}{c}-0.14 \\
(0.24)\end{array}$ \\
\hline
\end{tabular}

*High refers to exposure to full free primary education in 1976 while Low refers to exposure to full free primary education before 1976.

Second, a good instrument must satisfy exclusion restrictions and the UPE program meets this criterion too, as the only means through which the program affects income is exclusively through its effect on schooling. This condition could be violated if the program implementation affected school quality. First, the possibility that program implementation affected the quality of teachers and their present income was investigated, noting no evidence of such a relationship. ${ }^{10}$ Also, the possibility that program implementation caused a temporary fall in the quality of education, which affects income, was ruled out upon investigation using simple

\footnotetext{
${ }^{9}$ For the analysis in Table 1, a high intensity region is one that did not have significant exposure to free primary education at all levels before 1976. In contrast, a low intensity regions is one that has had free primary education at all levels before 1976. Table 1 Panel A shows that school attainment increased more in high intensity regions though as expected, school attainment is higher in the low intensity region. The estimate of the causal effect of the program in Panel A and $\mathrm{B}$ is not significantly different from 0 at $95 \%$. However at $90 \%$ the estimate is significant for panel A, the experiment of interest.

${ }^{10}$ In addition, teachers in Nigeria are paid primarily on qualification and years of experience and not on the basis of their performance or quality of education.
} 
tests similar to those in Duflo (2001). For example, I find no systematic correlation between teacher-student ratios and program implementation over time. ${ }^{11}$

Third, a good instrument is strictly exogenous, meaning it is not correlated with any unobservable in the earnings equation. This criterion is the hardest to prove. However, I argue that this instrument is exogenous for many reasons. First, the implementation of the policy was not as a result of a democratic choice, and hence to a large extent does not reflect popular preferences. As the program was implemented in a colonial and military setting, program implementation across region and time reflects various commanders' preferences. $^{12}$ Besides, the initial phase in of the program was not in any way related to the Western region having a higher value for education than the East or Midwest. In fact prior to the program implementation, enrollment rates were highest in the Eastern region of the country. Also, the program was the idea of an officer in charge of education in a particular region, who had a particular ideology or preference.

A clear example of how an individuals' preference drove policy implementation is the case, of then military ruler Olusegun Obasanjo who made the program nationwide in 1976 when he assumed power. Though the program was scrapped two years after his regime ended, he once again reintroduced the program in 1999 (when oil prices were at its lowest in more than 10 year), over 20 years later, when he was sworn in as the second civilian president of Nigeria, further extending the program to the first three years of secondary education. Unlike many other past

\footnotetext{
${ }^{11}$ I also estimated the returns to education across the Northern and Southern regions for the cohort exposed to the full implementation of the UPE in 1976. If implementation affected quality, then for the cohort exposed to the program, returns to education should be lower and significantly different for individuals from the high intensity regions in comparison to individuals from the low intensity regions. However, returns to education are not significantly different. In addition, I estimated returns to education across cohorts. If the UPE affected quality of education for the cohorts exposed to the program, there should differences in returns across cohorts. However, returns to education are not statistically different across cohorts.

${ }^{12}$ It is possible to tell a story where commanders try to meet people's preferences but this can be ruled out in the Nigerian case based on historical facts leading to program implementation.
} 
leaders, he is convinced this program is essential to Nigeria's educational progress and shares a similar ideology to the officer who first suggested the idea.
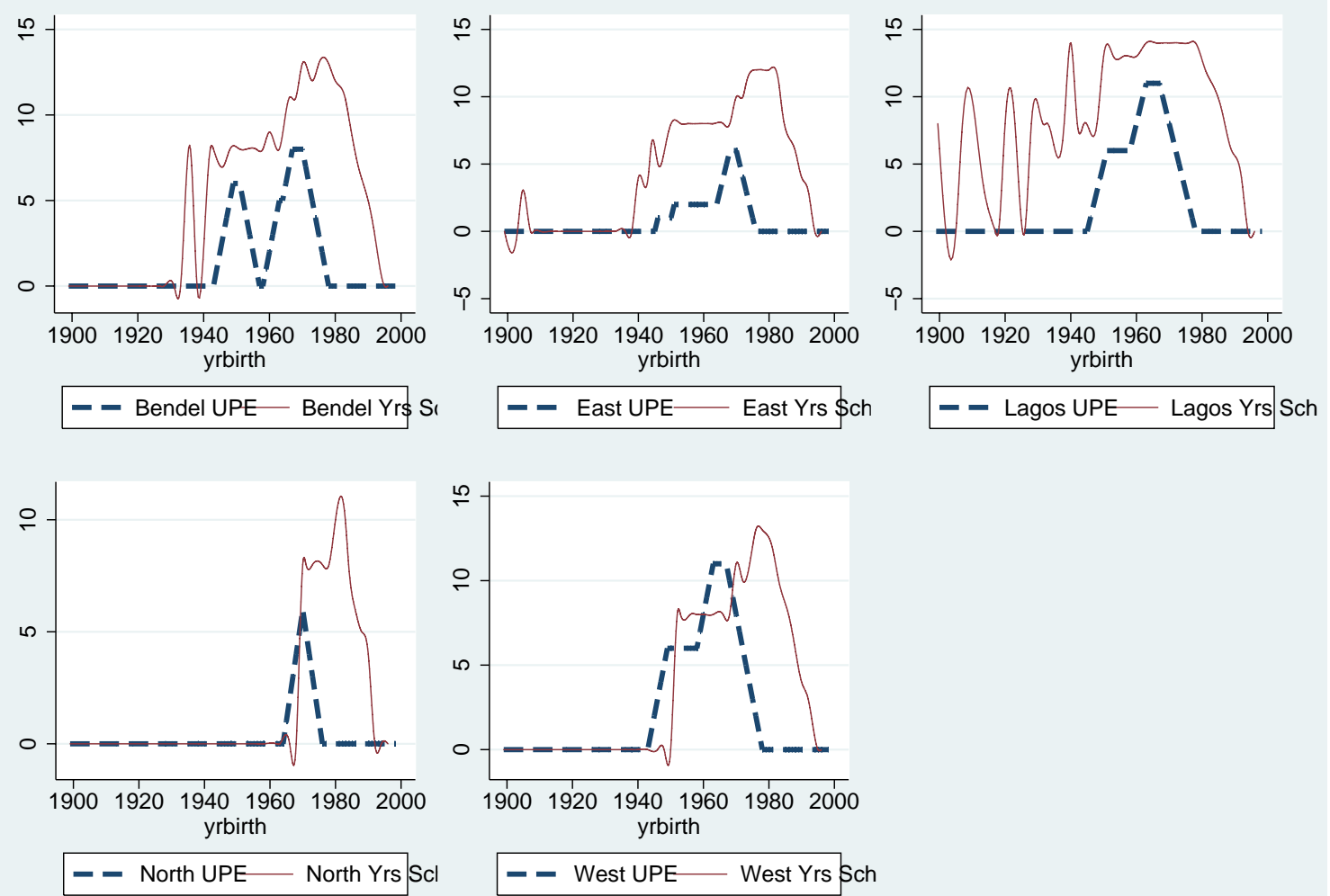

Figure 2: Trends in school attainment and exposure by UPE-region

Detailed documentation on the history and administration of the program confirm that timing of implementation was arbitrary and not influenced by resource booms or regional/political factors. This means the choice of location for the initial implementation and length was not linked to non-random regional factors. For example, the phasing in of the program in the 50s was not linked to a resource boom in the West neither was the collapse of the program linked to the fall in oil prices but a shift of handling education to the state government. Based on the 
above arguments and other research into the program implementation, I argue the UPE instrument is exogenous.

Finally, as mentioned earlier, recent studies have critiqued the instrumental variable approach for several reasons such as instruments being weak with insignificant estimates and estimates being inconsistent as they are correlated with unobservable ability in the wage function. This is not the case for the UPE instrument. Figure 2 captures the relationship between birth cohort, exposure to free education and school attainment across UPE-regions in Nigeria. While Figure 3 captures the relationship between the instrument, years of schooling and log income. These figures provide evidence against the weak instrument argument in the case of UPE. ${ }^{13}$ In addition, ability does not affect exposure to the free primary education program. Hence, not controlling for ability cannot bias or weaken the instrument.

However, it is important to mention that the lack of schools in towns and villages was common in the early periods of the program implementation especially in the late 50s to early 70s. Unfortunately, I do not know exactly which towns in the regions did not have schools. This lack of schools varied across states and was more common in the rural areas and in the northern parts of Nigeria. Even in the 80s, some rural areas of the north lacked primary schools (see Hass (2003) for more information). Hence, constructing the instrument without taking into account the fact that many people did not have schools in their towns and villages though in a region or state with program implementation can attenuate the impact of the instrument if the sample is small and/or contains few people truly exposed to free education ${ }^{14}$. In this scenario, the instrument may be weak. This is not a problem

\footnotetext{
${ }^{13}$ The first stage of the 2 SLS regression provides more substantive evidence against the weak instrument thesis.

${ }^{14}$ By truly exposed to free education, I mean those who had access to a primary school.
} 
in this analysis because the sample size is large $(68,201)$. However this problem can crop up if a small sub group of the population is considered.

Given all the arguments above, I argue that exposure to UPE is a reasonable instrument for school attainment, which can be used to derive consistent estimates of the returns to education.

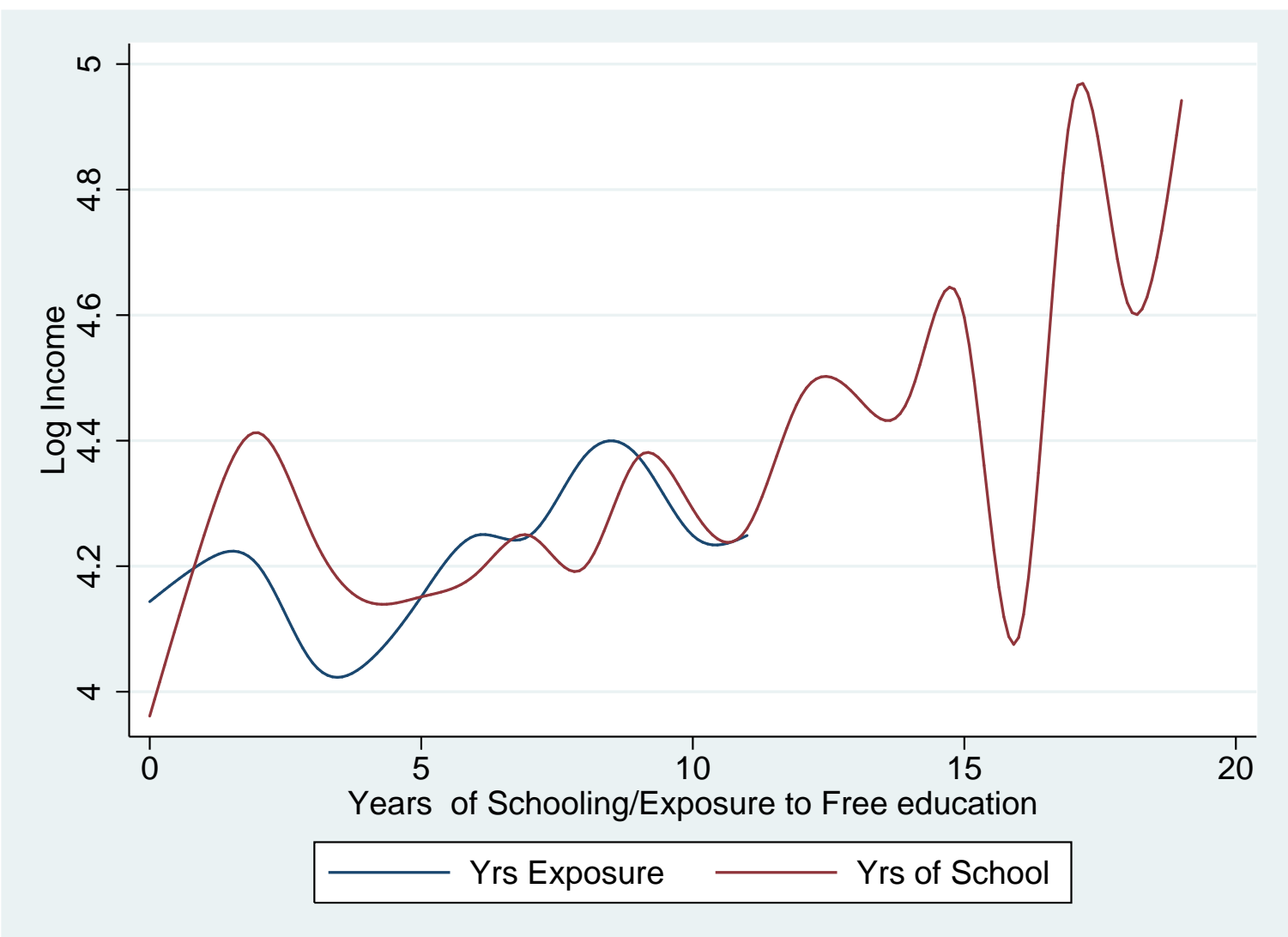

Figure 3: Trends in school attainment and exposure by UPE-region 


\section{Identification Strategy}

\subsection{Estimation Strategy}

To answer the question on what are the returns to education in Nigeria in the late 90s, I assume an endogenous schooling model. Equation (2) and (3) are estimated to derive the return to schooling using the instrumental variables (IV) approach. ${ }^{15}$

$$
\log \left(y_{i j k}\right)=\alpha+\beta S_{i j k}+\phi X_{i j k}+\kappa X_{i j k}^{2}+\rho Z_{i j k}+\epsilon_{i j k}
$$

Here $X_{i j k}$ is age of individual $i$ born in year $j$ in UPE region group $k, S_{i j k}$ is years of schooling of individual $i$ born in year $j$ in UPE region group $k, Z_{i j k}$ is a matrix of all other possible exogenous/control variables for individual $i$ born in year $j$ in UPE region group $k$ and $y_{i j k}$ is income of individual $i$ born in year $j$ in UPE region group $k$. The control variables used are sex, sector, cohort fixed effects, region/state fixed effects and year dummies.

$$
S_{i j k}=\lambda_{0}+\lambda_{1} X_{i j k}+\lambda_{2} X_{i j k}^{2}+\lambda_{3} Z_{i j k}+\lambda_{4} U P E_{i j k}+v_{i j k}
$$

$U P E_{i j k}$ is the exposure to free education of individual $i$ born in year $j$ in UPE region group $k, \epsilon_{i j k}$ and $v_{i j k}$ are uncorrelated error terms, $\alpha$ and $\lambda_{0}$ are the intercept terms and $\beta$ is the return to education/schooling.

As a benchmark, returns to education were first estimated using OLS on a simple Mincer-type earnings function as in equation (1). The $\beta$ estimate differs depending on if equation (1) is estimated alone or if it is estimated with equation (2) in a 2SLS estimation. In addition, this estimate differs depending on the controls used in both equation (1) and (2).

Estimates for returns to education are derived pooling the data of the two surveys together. The returns to education are estimated for the whole working

\footnotetext{
${ }^{15}$ Issues of potential selectivity are addresses with other robustness checks later on the paper.
} 
population. However, estimations restricting the sample to those above age 22 (average age when college education is completed) do not change the results.

\subsection{Construction of the Instrument}

As stated in the introduction, the UPE instrument is constructed based on the length of exposure of an individual to free education. The argument here is the longer an individual is exposed to free education, the higher the years of school attainment. First, for every extra year of free education a parent can get for a child, the lower is the cost of achieving any higher level of education. Furthermore, if parents, due to lack of knowledge, are apprehensive of western education, as was the case in Nigeria (see Ozigi and Ocho (1981) for the Northern Nigeria case), the longer their children are exposed to education, the higher the probability parents will appreciate its value and be willing to pay for further education. In constructing the instrument, length of exposure to free primary education, or length of exposure to free education, whether primary or higher, can be used. The estimation results using either alternative are not significantly different. However, for completeness, I constructed the instrument as exposure to free education.

It is important to note that Osili and Long construct their instrument differently (see pp 14-16 Osili and Long (2003). They focus only on the formal implementation of the UPE in the 70s. I focus on implementation of free primary education since the idea started in 1955. Furthermore, they limit their sample to women of two cohorts: those born between 1958 and 1963 (age 13 to 18 when the program started) and those born between 1970 and 1975. I consider both men and women exposed to the program of free education in its different phases of implementation from 1955 to 1983. I however tried to replicate their estimation of the impact of the UPE using the GHS dataset. Both estimates, though different, are not statistically different. In both cases the estimates show the strong impact 
of the UPE on schooling. ${ }^{16}$

The instrument is constructed based on an interaction between year of birth and location. For example, individuals born in the north in 1970, were six years in 1976 when the program started nationwide. Since the program ended in 1981, such individuals would have been exposed to free primary education for six years. The variation in the instrument comes from different cohorts in different regions of the country being exposed to free education for different lengths of time. Figure 4 shows the potential years of exposure to free education for each birth cohort by UPE regions. It is this variation in cohorts exposed to free education, over time and across regions, that I exploit as an instrument for school attainment.

Lastly, a possible issue that could arise when using this instrument on the present data is migration. This potential problem exists because the data set does not contain information on where individuals were born or went to school but on individual's present location. Individuals could possibly be located in places different from where they went to school and the instrument potentially could be inaccurate for this group of people. In that scenario, our instruments might be weak. However, this is not the case in Nigeria. Most movements are within states from rural to urban areas and not across states which could affect the validity of the instrument. As was explicitly documented in FOS (1999), and FOS (2000), $95.3 \%$ and $95.8 \%$ of people were still living in the state where they were born. Moveover, the $4.2 \%$ who migrate mostly move within the same region. Hence, potential effects on the instrument should be negligible.

\footnotetext{
${ }^{16}$ The estimate of UPE impact (0.65) I tried to replicate was from table four of Osili and Long (2003). My estimate was 0.54 , but one can expect to find slight differences as different datasets are being used. They combine 1990 and 1999 of the Demographic household survey (DHS) while I am using 1997-1999 of the GHS. They also have control variables like religion which are not in the GHS dataset.
} 


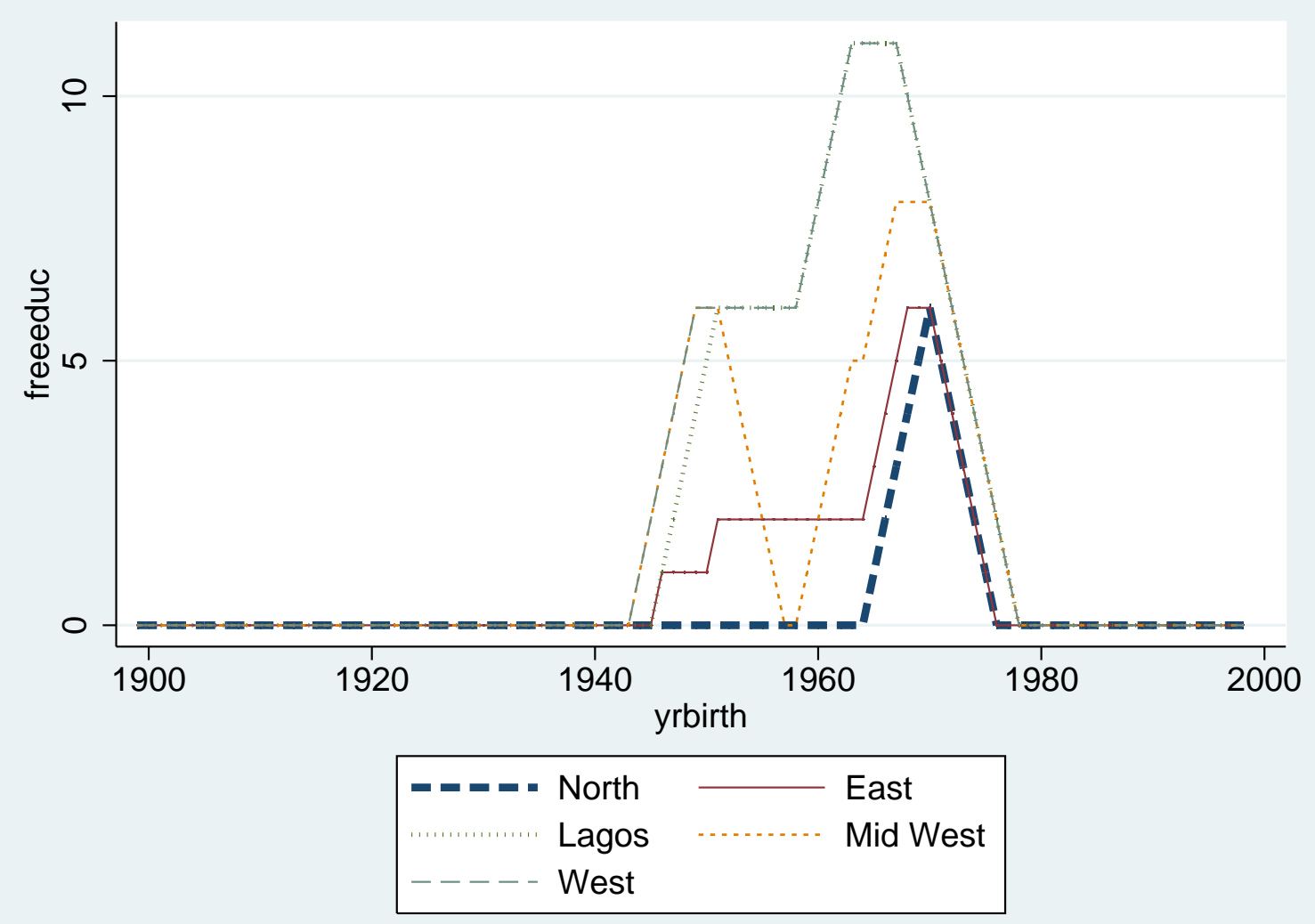

Figure 4: Exposure to free education by birth cohorts and UPE-region

\section{Description of Datasets}

In this paper, I made use of the General Household Survey (GHS). This is a government conducted survey. The GHS is one of the major sample surveys carried out under the National Integrated Sample Survey of Households (NISH) program of the Federal Office of Statistics (FOS) in Nigeria and makes use of a two-stage replicate sample design, which is a common random sampling procedure. It is the only survey in Nigeria that resembles the Living Standards Measurement Survey (LSMS) of the World Bank in terms of variable coverage. The FOS in Nigeria 
conducts this survey yearly and data are collected from randomly selected households all over the country during the four quarters of the year. ${ }^{17}$ To ensure that the data are comparable over time and across regions, current monetary values were deflated to 1985 base year prices.

The GHS data set is appropriate for the analysis since it consists of detailed information on several demographic and economic indicators of all individuals within the household including income, location and other household characteristics. A drawback of the survey is that different households are surveyed in each survey year. The survey periods I use are 1997/1998 and 1998/1999. I have data on 131,477 people from 32,024 households in $1997 / 98$ and 106,325 people from 24,889 households in 1998/99. ${ }^{18}$ Data from these two surveys are comparable and can be pooled as the same sampling procedure was used in the two surveys.

Table 2 presents summary statistics of some important variables, for both survey years. Columns (3) and (4) provide information restricting the sample to income earners and columns (5) and (6) present the summary statistics pooling both surveys. Although real mean income increased slightly over the two years being studied, estimates are not significantly different.

\section{Estimation and Results}

\subsection{Estimation of Returns to Education}

Table 3 is a summary of the results of the estimation of equation (1) and (2) using both OLS and 2SLS. The first part of columns (2), (4), (6), (8), (10) highlight the 1st stage estimates of the instruments impact on school attainment. The second

\footnotetext{
${ }^{17}$ Note different households in each enumeration area are interviewed in each quarter.

${ }^{18}$ For the first quarter of $1998 / 99$ the data set was missing.
} 
Table 2: Summary Statistics

\begin{tabular}{ccccccc}
\hline \hline Year & $1997 / 98$ & $1998 / 99$ & $1997 / 98$ & $1998 / 99$ & Pooled & Pooled \\
\cline { 2 - 7 } & $($ All $)$ & $($ All $)$ & Inc. Earners & Inc. Earners \\
$(1)$ & $(2)$ & $(3)$ & $\begin{array}{c}\text { ALL } \\
(5)\end{array}$ & $\begin{array}{c}\text { Inc. Earners } \\
(6)\end{array}$ \\
\hline Observations & 131,477 & 106,325 & 38,131 & 30,070 & 237802 & 68201 \\
\hline Age & 23.49 & 23.32 & 42.42 & 42.85 & 23.4 & 42.61 \\
& $(18.05)$ & $(18.21)$ & $(13.24)$ & $(13.51)$ & $(18.12)$ & $(13.36)$ \\
Sex & 0.523 & 0.516 & 0.71 & 0.69 & 0.42 & 0.70 \\
(male=1) & $(0.5)$ & $(0.50)$ & $(0.45)$ & $(0.46)$ & $(0.50)$ & $(0.46)$ \\
Sector & 0.241 & 0.236 & 0.288 & 0.281 & 0.24 & 0.28 \\
(urban=1) & $(0.43)$ & $(0.43)$ & $(0.45)$ & $(0.45)$ & $(0.43)$ & $(0.45)$ \\
Years sch & 4.2 & 4.17 & 5.13 & 5.19 & 4.19 & 5.15 \\
& $(5.10)$ & $(5.17)$ & $(5.82)$ & $(5.89)$ & $(5.13)$ & $(5.86)$ \\
HH size & 6.12 & 6.337 & 4.73 & 4.87 & 6.23 & 4.72 \\
& $(3.34)$ & $(3.5)$ & $(3.0)$ & $(2.9)$ & $(3.49)$ & $(2.03)$ \\
Income & 26.88 & 26.51 & 92.67 & 93.73 & 26.71 & 93.14 \\
& $(166.05)$ & $(94.37)$ & $(298.30)$ & $(158.7)$ & $(138.67)$ & $(246.68)$ \\
\hline \hline
\end{tabular}

* Note: Standard deviation in bracket.

Inc. Earners refers to income earners

part of columns (2), (4), (6), (8), (10) highlight the 2SLS estimates of returns to education while columns (1), (3), (5), (7), (9) highlight the comparable OLS estimates. I also include the reduced form estimates of the instrument on wages at the bottom of Table 3. To highlight the importance of including controls, I estimate the returns to education with and without some controls. The preferred 2SLS estimates are in column (10). In this column, apart from the standard variables in a Mincer equation (age and year of schooling), other controls such as cohorts, sector, age-squared, sex, state dummies and year fixed effect are included. All estimations were carried out correcting for potential heteroskedacity and clustering by age.

The first stage result points to the impact of the program on attainment. The reduced form estimates point to the direct impact of the program on wages. Column (10) shows that even with state controls included, for every year of exposure 
Table 3: Summary of 2SLS Results OLS vs IV (1997-1999)

\begin{tabular}{|c|c|c|c|c|c|c|c|c|c|c|}
\hline $\begin{array}{c}\text { Variable } \\
\text { of Interest }\end{array}$ & $\begin{array}{c}\text { (OLS) } \\
(1)\end{array}$ & $\frac{\overline{(I V)}}{(2)}$ & $\frac{\overline{(\mathrm{OLS})}}{(3)}$ & $\frac{\overline{(I V)}}{(4)}$ & $\frac{\overline{(O L S)}}{(5)}$ & $\frac{\overline{(I V)}}{(6)}$ & $\begin{array}{c}\text { (OLS) } \\
(7)\end{array}$ & $\begin{array}{c}\text { (IV) } \\
(8)\end{array}$ & $\begin{array}{c}\text { (OLS) } \\
(9)\end{array}$ & $\begin{array}{l}\text { (IV) } \\
(10)\end{array}$ \\
\hline \multicolumn{11}{|c|}{ 1st Stage Results (Dependent Variable: Year of Schooling) } \\
\hline UPE Exposure & NA & $\begin{array}{c}0.56^{*} \\
(0.008)\end{array}$ & NA & $\begin{array}{c}0.41^{*} \\
(0.008)\end{array}$ & NA & $\begin{array}{c}0.42^{*} \\
(0.009)\end{array}$ & NA & $\begin{array}{c}0.18^{*} \\
(0.011)\end{array}$ & \multirow{3}{*}{ NA } & \multirow{3}{*}{$\begin{array}{c}0.15^{*} \\
(0.011) \\
0.36\end{array}$} \\
\hline$R^{2}$ & NA & 0.15 & NA & 0.21 & NA & 0.22 & NA & 0.33 & & \\
\hline \multirow{3}{*}{\multicolumn{11}{|c|}{$\begin{array}{ccccccc}0.069^{*} & 0.036^{*} & 0.058^{*} & 0.036^{*} & 0.058^{*} & 0.030^{*} & 0.052^{*} \\
(0.002 & (0.0004) & (0.003) & (0.001) & (0.003) & (0.001) & (0.011) \\
\text { Reduced Form Estimate (Dependent Variable: Log Income ) }\end{array}$}} \\
\hline & & & & & & & & & & \\
\hline & & & & & & & & & & \\
\hline UPE Exposure & $\begin{array}{l}0.039^{*} \\
(0.001)\end{array}$ & & $\begin{array}{l}0.024^{*} \\
(0.002)\end{array}$ & & $\begin{array}{l}0.025^{*} \\
(0.001)\end{array}$ & & $\begin{array}{l}0.009 * \\
(0.001)\end{array}$ & & $\begin{array}{l}0.004 * \\
(0.001)\end{array}$ & \\
\hline Controls & \multicolumn{2}{|c|}{ Year \& Sex } & \multicolumn{2}{|c|}{+ Sector } & \multicolumn{2}{|c|}{+ Cohort } & \multicolumn{2}{|c|}{+ Region } & \multicolumn{2}{|c|}{+ States -Region } \\
\hline
\end{tabular}

to free education, school attainment increased by 0.15 of a year. Notice without control for state or region, the impact of exposure is nearly a 0.5 increase in school attainment for a year of exposure. What is striking from Table 3 is the low return to education using both the IV and OLS approach, once important controls are included. It is important to note that just controlling for region as in the results in column (8) is not sufficient for the Nigerian case because of the importance of some states as trade centers, capital, or having a seaport or crude oil. A region dummy would not control for these state fixed effects, necessitating the inclusion of state fixed effects in the Nigerian case. ${ }^{19}$. Based on the results from column (10), the return to an extra year of schooling is $2.7 \%$. Another quite unexpected finding is that the OLS and IV estimates are very similar. The OLS estimates are lower than the 2SLS estimates in all estimations but the estimates are not statistically different.

\footnotetext{
${ }^{19}$ If states within a region are similar there might be no need for state dummies and region dummies may suffice but this is not the case for all regions in Nigeria.
} 
The above results do not categorically establish the return to education to be very low for everyone in Nigeria for the years in question. This is because return to education can be heterogenous. Recall that all that is being estimated is the average return to an extra year of schooling for the entire labor force. Hence, it might be useful to try to break down the population into groups to see if the results would change drastically or if the low return to education can be isolated for a subgroup in the population. In the next sub-section, returns to education will be estimated for subgroups of the population as both a robustness check on the results and to relate the results to particular groups in the country.

\subsection{Robustness Checks}

An issue one could raise, based on the above results, is centered on gender. In Nigeria, many claim that gender affects wages and it is possible that males and females have different returns to education. Also in Nigeria, the sector of the economy where an individual dwells and works can affect earnings. Hence, individuals in the rural and urban areas could have different returns to their education. Besides, there is clear difficulty in estimating income in the rural areas because people work mainly in the informal sector (farming, fishing, animal rearing) and it is very hard to isolate wages for individuals in these households. This problem of getting precise wage estimates for individuals in the rural areas is one possible reason to estimate returns separately for rural and urban areas and focus more attention on the average returns to education in the urban areas.

Using both OLS and the IV estimator, returns to education are estimated by gender and sector. Table 4 provides a summary of the returns to education for selected sub-groups of the population. The results of the sub-group analysis confirm some of the issues highlighted above. First, the impact of the program 
on men's and women's school attainment was the same. ${ }^{20}$ Second, the return to education for men is $4.7 \%$ for every extra year of schooling which is greater than the average returns to education estimate for the whole population but not significantly different. The estimate of the return to education for women is smaller than men but also not significantly different. Also from columns (3) to (6) of Table 4, one notices higher returns to education in the urban areas than in the rural areas, which is expected. However as in the case of the men and women, the estimates are not significantly different. More importantly, the differences in returns to education across these groups are compatible with earlier results. Returns to education in Nigeria was still below a $5 \%$ increase in income for every extra year of schooling in the late 90s. In addition, the estimates using OLS and IV are not significant different just as in Table 3. These estimates are clearly on the low side relative to estimates from other countries.

Another argument that can be made is that estimating the returns to education across sectors, or solely focusing on the urban sector, does not fully deal with the problem of precisely estimating individual income, which is necessary for a valid estimate on the returns to schooling. Many people in the urban areas are still involved in the informal sector, and for these individuals accurately estimating their earnings accounting for family free labor could be prone to error. ${ }^{21}$ Hence as a robustness check, the return to education is estimated for households containing a single individual. Here the problem of possibly overestimating the returns to education because of inability to adequately untangle individual earnings is removed. Table 4 columns (7) and (8) are a summary of the returns to earnings

\footnotetext{
${ }^{20}$ Table 4 shows only the returns for men (columns (1) and (2)). However returns for women were also estimated by the author.

${ }^{21}$ It is important to note that for the GHS surveys, survey staff are trained to tackle this problem of measuring individual income in the informal sector using standard computations. However, these computations may still be prone to errors.
} 
for the single-individual households. The impact of the instrument on schooling is larger but not significantly different from estimates from previous analysis. Also, the return to education for this group is higher than the average for the population but not statistically different.

In line with the question of accurately identifying the returns to education in the late 90s in Nigeria, another robustness check is to re-estimate the returns to education dividing the sample into wage earners and self employed. The argument is that the return to education can only be properly estimated for wage earners as wages are to a large extent a measure of productivity. Columns (9-12) of Table 4 are a summary of the returns to education estimate for wage earners and selfemployed. Due to the small sample size of wage earners (only $11 \%$ of the sample), problems mentioned earlier in the paper with respect to a weak instrument crop up. To get around this problem, estimates for wage workers are derived only for areas where impact of the phase in of the program would be strong. ${ }^{22}$ The interesting finding is that though the returns to education is higher for the wage workers, it is not significantly different from the self employed. This finding is contrary to the theory that education basically serves as a signal and really does not embody human capital. ${ }^{23}$ In addition, the results are again consistent with earlier results showing low returns to education, less than 0.05 , in the late $90 \mathrm{~s}$ in Nigeria.

Another possible form of bias that can affect precisely estimating the returns

\footnotetext{
${ }^{22}$ Specifically, I estimate the returns to education in areas of Nigeria, where a significant number of primary schools existed before 1980 based on information from the Federal Ministry of Eduction and FOS. For these areas, the instrument is more likely to capture true exposure. This is not a problem for the self-employed sub-group because the sample size is so large. However, to ensure that this analysis does not create a selection bias in the estimate for wage earners, I also estimate the returns for the self-employed for this sub-sample, as a test. The results show no significant difference between the estimate from the whole population and the estimate for the subgroup for the self employed (0.024 vs 0.025$)$. This simple test provides evidence against a selection bias created by considering a sub-sample.

${ }^{23}$ The estimates for wage earners and self-employed are not significantly different.
} 
Table 4: Robustness Checks: 2SLS Estimate of Returns to Education by Select Sub groups

\begin{tabular}{|c|c|c|c|c|c|c|c|c|c|c|c|c|}
\hline & \multicolumn{2}{|c|}{ Men } & \multicolumn{2}{|c|}{ Urban } & \multicolumn{2}{|c|}{ Rural } & \multicolumn{2}{|c|}{ Single PH } & \multicolumn{2}{|c|}{ Self Emp. } & \multicolumn{2}{|c|}{ Wage Worker } \\
\hline & $\begin{array}{c}\text { OLS } \\
(1)\end{array}$ & $\begin{array}{l}\text { IV } \\
(2)\end{array}$ & $\begin{array}{l}\text { OLS } \\
(3)\end{array}$ & $\begin{array}{l}\text { IV } \\
(4)\end{array}$ & $\begin{array}{c}\text { OLS } \\
(5)\end{array}$ & $\begin{array}{l}\text { IV } \\
\text { (6) }\end{array}$ & $\begin{array}{l}\text { OLS } \\
(7)\end{array}$ & $\begin{array}{l}\text { IV } \\
(8)\end{array}$ & $\begin{array}{l}\text { OLS } \\
(9)\end{array}$ & $\begin{array}{c}\text { IV } \\
(10)\end{array}$ & $\begin{array}{l}\text { OLS } \\
(11)\end{array}$ & $\begin{array}{c}\text { IV } \\
(12)\end{array}$ \\
\hline UPE & NA & $\begin{array}{c}0.18^{*} \\
(0.012) \\
\end{array}$ & NA & $\begin{array}{c}0.114^{*} \\
(0.017)\end{array}$ & $\begin{array}{r}\text { Stage: } \\
\text { NA }\end{array}$ & $\begin{array}{c}\text { timate } \\
0.17^{*} \\
(0.012)\end{array}$ & $\begin{array}{c}\text { IV Imp } \\
\text { NA }\end{array}$ & $\begin{array}{c}\text { on Sch } \\
0.24^{*} \\
(0.025)\end{array}$ & $\begin{array}{r}\text { oling } \\
\text { NA }\end{array}$ & $\begin{array}{c}0.17^{*} \\
(0.009) \\
\end{array}$ & NA & $\begin{array}{c}0.13^{*} \\
(0.021) \\
\end{array}$ \\
\hline & & & & Sec & d Stage & Estimat & of Retu & to Sch & ling & & & \\
\hline RTE & $\begin{array}{c}0.024^{*} \\
(0.001)\end{array}$ & $\begin{array}{l}0.047^{*} \\
(0.009)\end{array}$ & $\begin{array}{l}0.031^{*} \\
(0.001)\end{array}$ & $\begin{array}{c}0.043^{*} \\
(0.016)\end{array}$ & $\begin{array}{c}0.024^{*} \\
(0.001)\end{array}$ & $\begin{array}{c}0.026^{*} \\
(0.009)\end{array}$ & $\begin{array}{c}0.032 * \\
(0.001)\end{array}$ & $\begin{array}{c}0.032^{*} \\
(0.012)\end{array}$ & $\begin{array}{l}0.022^{*} \\
(0.001)\end{array}$ & $\begin{array}{c}0.025^{*} \\
(0.007)\end{array}$ & $\begin{array}{l}0.031^{*} \\
(0.002)\end{array}$ & $\begin{array}{c}0.044^{*} \\
(0.02)\end{array}$ \\
\hline Controls & Yes & Yes & Yes & Yes & Yes & Yes & Yes & Yes & Yes & Yes & Yes & Yes \\
\hline
\end{tabular}

Note: * $5 \%$ significance levels

Controls used for columns (1) to (10) are age, agesq, sex, sector, year and state dummies.

Estimates in columns (1) to (10) are derived using the full sample. The sub-sample used for estimates in column (11) and (12) consists of all South Western states, parts of the Mid-Belt, South South, North West, North East and South East of Nigeria. Controls used are age age squared sex, sector, year dummy and state dummies that are jointly significant.

to schooling is selectivity. This issue would be addressed in the next section.

The findings in this section confirm that the average return to education in Nigeria in the late $90 \mathrm{~s}$ is low. These results also indicate that OLS estimates of returns to education are slightly lower than IV estimates. Finding OLS estimates lower than IV estimates is not peculiar as many authors have found higher IV estimates of returns to schooling than OLS (See Card, 1999). However, what is unique in the Nigerian case is that OLS estimates are not significantly different from the IV estimates. Hence, the OLS estimate of average returns to schooling in Nigeria is not biased. More importantly, the low returns to education cuts across subgroups of the population and is in general lower than what some past researcher have reported to be characteristic of Africa and developing countries in general (see Psacharopoulos and Patrinos, 2004).

\subsection{Correcting for Selectivity}

As precise and consistent estimates of returns to education are sought, a potential source of bias, common when estimating earning equations, self-selection bias is 
corrected for. That is, if individuals can choose whether to be within the work force based on individual self-selection, then the schooling variable will be a dependent rather than independent variable. Thus, ordinary least squares (OLS) estimates of schooling will be inconsistent. One way to check and correct for selection bias based on the pioneering work of Heckman (1979), is to calculate the inverse Mills ratio, add it as an additional regressor in the earnings equation and run a simple OLS to see if its coefficient is significant. ${ }^{24}$ This simple test of self selection was carried out and the coefficient on the inverse mill ratio was significant. Similar results were obtained when including the Mills ratio in the second stage of a 2SLS analysis using the instrument. However, in all cases the coefficient on schooling did not change significantly from its previous value without the correction (see Table 4 columns (3) and (4)). Column (3) shows estimates of returns to schooling correcting for selectivity using the MLE with a Heckman correction model and column (4) shows estimates using the Heckman two step estimation procedure. Though these estimates are closer to the OLS and lower than the 2SLS estimates, they are also not significantly different. Inferring that the selection bias, created by deriving estimates from only those working, does not significantly affect returns to education estimates.

The above method has come under criticism for relying on unverifiable assumptions about the unobservable and functional form of the selection model to obtain identification. In addition, there are arguments that there are other potential sources of self selection not captured via this means. For example when estimating the wage equation, log of earnings is observed only for those working. Hence, a correlation can exist between the instrument and the error term for those working when conditioning on the instrument if the probability of being employed is correlated with schooling and hence the instrument (Angrist, 1997).

\footnotetext{
${ }^{24}$ Here one assumes that the error terms are jointly normal and independent of the instruments.
} 
To address this potential selection bias, corrections are made to estimates using the propensity score. According to (Angrist, 1997), a general control for selection bias requires only the existence of a function such that the error term of the outcome equation is independent of the instrument. However, for the propensity score to serve as a conditioning variable in the presence of selection bias, the error term and selection status are assumed to be jointly independent of the instrument and also the error term is independent of the function. ${ }^{25}$

To implement the propensity score correction, first, the propensity score of working is estimated. I make use of both a probit and a linear model in this selection model estimation. The next step is to derive the predicted value of schooling, using equation (2). Then estimate equation (2) with other covariates, the propensity score and predicted value of schooling.

Table 5 columns (5) and (6) show the estimate of the returns to schooling assuming a linear and a probit model. These results provide further evidence that selectivity is not an important issue in this analysis as comparisons between the 2SLS estimates of returns to schooling with controls are very similar to estimates after correcting for potential selectivity.

Identification is sought through the propensity score estimation using a probit model. Therefore the preferred estimate of average returns to education in Nigeria using the pooled data is $2.8 \%$ for every extra year of schooling. ${ }^{26}$ This estimate of average returns to education in Nigeria is lower than estimates for other African countries.

\footnotetext{
${ }^{25}$ To see why these assumptions are sufficient to control selection bias when conditioning on propensity score see (Angrist, 1997), pp 106. It is important to mention that recent literature has highlighted that these assumption are restrictive.

${ }^{26}$ The pooled regression estimate is lower than the estimates for the 1997/98 cross-section. However, the estimates are not significantly different.
} 
Table 5: Estimates of Returns to Education after Correcting for Selectivity

\begin{tabular}{|c|c|c|c|c|c|c|}
\hline & $\begin{array}{l}\text { OLS } \\
(1)\end{array}$ & $\begin{array}{c}\text { 2SLS } \\
(2) \\
\end{array}$ & $\begin{array}{c}\text { Heckman } \\
(3) \\
\end{array}$ & $\begin{array}{c}\text { Heckman2 } \\
(4)\end{array}$ & $\begin{array}{c}\text { pscore (linear) } \\
(5)\end{array}$ & $\begin{array}{c}\text { pscore (probit) } \\
(6)\end{array}$ \\
\hline 1st Stage Results & \multicolumn{6}{|c|}{ Using the Length of Exposure Instrument } \\
\hline Impact of UPE & NA & $\begin{array}{c}0.146 \\
(0.011)\end{array}$ & NA & NA & $(0.0)$ & $(0.0)$ \\
\hline 2nd Stage Results & \multicolumn{6}{|c|}{ Dependent Variable Log Income } \\
\hline Year of Schooling & $\begin{array}{l}0.026^{*} \\
(0.001)\end{array}$ & $\begin{array}{l}0.027^{*} \\
(0.009)\end{array}$ & $\begin{array}{l}0.027^{*} \\
(0.001)\end{array}$ & $\begin{array}{l}0.027^{*} \\
(0.001)\end{array}$ & $\begin{array}{l}0.027^{*} \\
(0.009)\end{array}$ & $\begin{array}{l}0.028^{*} \\
(0.009)\end{array}$ \\
\hline Controls & yes & yes & yes & yes & yes & yes \\
\hline $\begin{array}{l}\text { Note: }{ }^{*} 5 \% \text { significance levels } \\
\text { NA-Not Applicable } \\
\text { pscore (linear)-IV estimation } \\
\text { pscore (probit) -IV estimation } \\
\text { Heckman-Heckman estimation } \\
\text { Heckman2-Heckman estimatior } \\
\text { Control include age agesq, coh }\end{array}$ & $\begin{array}{l}\text { propensit } \\
\mathrm{h} \text { propens } \\
\mathrm{hg} \text { maxim } \\
\text { ing a two } \\
\text { year and }\end{array}$ & $\begin{array}{l}\text { score adjust } \\
\text { score adju } \\
\text { likelihood } \\
\text { ep procedur } \\
\text { ate fixed ef }\end{array}$ & $\begin{array}{l}\text { nt with a } 1 \\
\text { ent with a }\end{array}$ & $\begin{array}{l}\text { probability } \\
\text { it model. }\end{array}$ & & \\
\hline
\end{tabular}

\subsection{Comparison to Other Estimates for Africa}

Average returns to education in Nigeria are low but the question is whether this is a Nigeria phenomenon or there is a possibility returns are being over estimated for other African countries. Earlier on in this paper, recent studies estimating returns to education in most parts of Africa were highlighted. These papers had returns to education typically over $6 \%$ increase in income for every extra year of schooling. In fact most of these papers had returns well over $10 \%$ (see Table 6 for examples of such estimates). ${ }^{27}$ To state specifically a few example, Jones (2001) estimates average returns in Ghana at 8.1\% and Lassibille and Tan (2005) estimate approximately a $17.5 \%$ return in Rwanda. Siphambe (2000) estimates for Botswana a returns of approximately 12\% and Zgovu and Ephraim (2000) estimate returns for Malawi, noting returns between $5 \%$ and $10 \%$ depending on

\footnotetext{
${ }^{27}$ There are a few papers on Africa that find low returns to education at a particular level of education. Examples of such studies are Aromolaran (2004) for Nigeria (as low as 1.5\%), Kahyarara et al. (2004) for Tanzania (as low as 3.4\%), Dalben (1998) for South Africa (4.1\%) and Siphambe (2000) for Botswana (as low as 3.3\%)
} 
group analyzed. More generally, Psacharopoulos (1994) estimate the returns to education for several African countries, noting an average return over $8 \%$ for every extra year of schooling. These few examples from the literature are in contrast with the preferred result in this paper. However, these results are closer to the findings for Nigeria if estimates are derived without including controls in the estimation (see Table 3). ${ }^{28}$ Although estimates of returns to education, for Nigeria, without controls are still lower than many other estimates in other parts of Africa.

A careful analysis of the above mentioned papers, and others focused on African countries highlighted in the literature review, revealed that minimal controls were used in many of these studies. ${ }^{29}$ For example in estimating returns in Malawi, no controls for gender and location are included. Similarly for Rwanda and Botswana. It is important to note that most of these papers put in some type of control variable though minimal. ${ }^{30}$

Adequate controls are needed to be able to attenuate omitted variable bias in estimating returns to education. Wages in most parts of Africa are affected by gender and sector of residence and as much as possible, these two factors affecting income need to be controlled for. Estimations using OLS and other methods that do not adequately deal with the endogenous nature of schooling coupled with inadequate controls may lead to biased estimates of returns to schooling.

\footnotetext{
${ }^{28}$ Also as a simple experiment, I estimate the regression without any controls apart from age and age-squared, noting between 2-3 percentage point increase in point estimates.

${ }^{29}$ Glewwe (1996) is one paper that uses adequate controls. Interestingly, He finds low returns to education, which is similar to the finding of this paper.

${ }^{30}$ As mentioned in the literature review, many papers try to correct for selectivity but some lack basic controls like location, sector and gender.
} 
Table 6: Average Returns to Schooling Estimates in Africa

\begin{tabular}{ccccc}
\hline \hline Authors & Country & Time & \multicolumn{2}{c}{ Schooling Coefficients } \\
\cline { 3 - 5 } & & \multicolumn{2}{c}{ OLS } & IV \\
\hline Psacharopoulos (1994) & Botswana & 1979 & $19.1 \%$ & \\
Psacharopoulos (1994) & Bukina Faso & 1980 & $9.6 \%$ & \\
Psacharopoulos (1994) & Cote d'ivoire & 1986 & $20.1 \%$ & \\
Psacharopoulos (1985) & Kenya & 1970 & $16.4 \%$ & \\
Schultz (1994) & Cote d'Ivoire & 1987 & $12.1-13.6 \%$ & \\
Ram and Singh (1988) & Burkina Faso & 1980 & $9.6 \%$ & \\
Dabalen (1998) & South Africa & 1994 & $4.1 \%$ & $19.1-28.1 \%$ \\
Mokitimi and Nieuwoudt (1995) & Lesotho & 1987 & $10.6-16.5 \%$ & \\
Ephraim \& Zgovu (2001) & Malawi & 2000 & $9.41 \%$ & \\
Glewwe (1996) & Ghana & 1989 & $7.3 \%-8.5 \%$ & $0-3.9 \%$ \\
Siphambe (2000) & Botswana & $1993 / 94$ & $12 \%$ & \\
World Bank (1996) & Ghana & 1992 & $9.3-10.6 \%$ & \\
Lasbille and Tan (2005) & Rwanda & $1999-2001$ & $17.5 \%$ & \multirow{2}{*}{$15 \%$} \\
Dabalen (1998) & Kenya & 1994 & $16.0 \%$ & \\
Cohen and House (1994) & Sudan & 1994 & $9.3 \%$ & \\
Jones (2001) & Ghana & 1995 & $7.1 \%$ & \\
\hline
\end{tabular}

Note: Summary derived partly from Psacharopoulos and Patrinos (2004). In some studies a range of estimates are provided because returns to education was calculated for men and women separately or for wage and nonwage workers separately.

\section{Implications and Conclusions}

\subsection{Implications of Results}

The above results show that average returns to education were extremely low in Nigeria between 1997 and 1999. Why do we care about these results?

First, low returns to education can discourage investment in education. This is crucial if education has large social returns and externalities. Furthermore, if education investments positively affect human capital and growth, then less investment in education cannot be beneficial. A clear indicator that individuals are investing less in education was reflected in falling enrollment rates and also a decline in quality of education noted in Nigeria over the 90s (see Malik (1997) 
and FOS (2000)). ${ }^{31}$

Second, low returns to education in Nigeria can lead to individuals finding alternative investments (also leading to fall in school enrollment). It can also lead to individuals who already have invested in education seeking international markets where there are higher returns to their education or switching to rent-seeking activities. These three reactions to low returns to education were common place in Nigeria and many other countries in Africa in the 90s. ${ }^{32}$ According to a study by the Geneva-based intergovernmental body, the International Organization for Migration (IOM), and the UN's Economic Commission for Africa (ECA), Africa lost 60,000 professionals (doctors, university lecturers, engineers, etc) between 1985 and 1990 (see Aredo and Zelalem, 1998). Even though this is not a large chunk of professionals within Africa, it is still significant. Moreover, this form of emigration can only be a road block to the growth and development of a country. Hence, continued low return to education in Nigeria compared to elsewhere is a sure stimulus for more of this kind of emigration if unrestricted. ${ }^{33}$

Lastly, these results indicate returns to education within the range of $2-5 \%$ for Nigeria though most earlier studies have estimated returns to education, in the range of $5-15 \%$, for other African countries using OLS techniques with few controls (see Psacharopoulos and Patrinos (2004)). Given this gap in estimates,

\footnotetext{
${ }^{31}$ Although gross enrollment rose over the 90 s at all levels of education, the enrollment rates for both primary and secondary education dropped significantly in the mid 90s and dropout rates rose dramatically. The decline in the quality of education over the 90 s was linked to many factors amongst which are incessant strikes and school closing, a rise in teacher student ratios, change in secondary education system and inadequate school input, political instability and declining government allocation to education. This downward trend has slowly been reversed with the change to civilian rule since mid 1999.

${ }^{32}$ Although it is widely documented that many Nigerian emigrated in the 90 s, specific data relating to emigration from Nigeria is not available.

${ }^{33}$ Immigration to most of the western world from developing countries especially Africa became more difficult in the $90 \mathrm{~s}$ and restriction by receiving countries have only tightened over time(less than $5 \%$ of visa applications to developed countries especially North America and Europe are granted). These restriction have curbed emigration from Africa significantly. However, high visa applications up until now indicates individuals preference for immigrating.
} 
there is a possibility that returns to education are being overstated for some other countries in Africa. This possibility could explain why the private economic value of education is being questioned not only in Nigeria but in these other African countries. $^{34}$ Moreover, preference to immigrate, especially for educated labor, is not a Nigerian phenomena solely but a Sub-Saharan phenomena. Hence, low returns to education may not be peculiar to Nigeria within Africa.

\subsection{Conclusions}

From the above analysis, it has been established using the unique instrument (UPE) that the average returns to education in Nigeria was low between 19971999. A consistent estimate of the average returns to an extra year of schooling, during this time period, is $2.8 \%$. Meaning that for every extra year of schooling, on average, there is less than a $3 \%$ increase in wages. This low estimate of return to education is robust to other specifications (meaning estimates are not significantly different) and is generally lower than estimates for other African countries. In addition, the results highlight the importance of including controls when estimating returns to education.

This paper contributes to the literature by providing more reliable estimates of returns to education in a West African country using the instrumental variable approach. Furthermore, the results show returns to education estimates in Nigeria that are lower than what is thought to be characteristic of Africa. The results also emphasizes the importance of including control when estimating the Mincer wage equation. Finally, several explanations have been sought for the changing demand for education, the increase shift to rent seeking activities and increased emigration rates from Nigeria over the 90s. The low average return to education in Nigeria in the 90s suggest a reasonable explanation for these phenomena. In addition, these

\footnotetext{
${ }^{34}$ Examples of such countries include Kenya \& Cote d'Ivoire.
} 
findings suggest the need to find instruments and re-estimate returns to education with appropriate controls in other African countries.

The work presented here has limitations. The returns to education estimates are averages for the population or sub-groups in the population. As mentioned in the literature review, recent work points to heterogeneity of returns across individuals which has not been accounted for in this paper. It is also important to note that even though the instrument used in this analysis had very large effects on schooling and affected a wide group of people, as Angrist and Imbens (1995) highlighted, returns to education estimates using a treatment may only capture a weighted average of the returns to education for those affected by the instrument. Another limitation of this analysis is the assumption of a linear relationship between wages and schooling.

Finally, in terms of policy recommendation, the present Nigerian government should focus on understanding why returns to education are low. One way of doing this, is to sponsor further surveys and analysis aimed at understanding this finding. ${ }^{35}$ The question of why returns to education are low in Nigeria still need answers and also, reestimating returns to education in other African countries using the IV strategy and accounting for heterogeneity, are interesting areas for further research.

\section{Acknowledgment}

This paper is based on my $\mathrm{PhD}$ dissertation at the University of California, Berkeley. The research has received funding partly from the Center for African Studies University of California, Berkeley. The author would like to especially thank Brian Wright for invaluable advice, patience and support of this work. I am also

\footnotetext{
${ }^{35}$ In Uwaifo (2006) The role of government and poor institutions in explaining partly the low returns to education is addressed.
} 
indebted to Edward Miguel, Jenny Lanjouw, Chris Udry, Alain de Janvry and two anonymous referees for their comments and useful advice. Adebayo Aromolaran was instrumental in securing the datasets. This work has benefitted from helpful comments from participants in the development workshops and seminar at University of California Berkeley and development workshop at Yale University. Of course, all remaining errors are mine. 


\section{References}

Adesina, S., 1988. The Development of Modern Education in Nigeria. Ibadan: Heineman Education Books.

Angrist, J., 1997. Conditional independence in sample selection models. Economic letters 54:103-112.

Angrist, J. and Krueger A., 1991. Does Compulsory School Attendance Affect Schooling and Earnings. Quarterly Journal of Economics 106: 979-1014.

Angrist, J. and Imbens G., 1995. Two-Stage Least Squares Estimation of Average Causal Effects in Models with Variable Treatment Intensity. Journal of the American Statistical Association 90(430): 431-442.

Aromolaran, A., 2004. Wage returns to schooling in Nigeria. African Development review 16(3):433-455.

Aredo, D. and Zelalem, Y., 1998. Skilled labor migration from developing countries: An assessment of brain-drain from Ethiopia. In Proceedings of the Seventh Annual Conference on the Ethiopian Economy, The Ethiopian Economic Association.

Ashenfelter, O. and Rouse, C., 1998. Income, schooling and ability; evidence from a new sample of identical twins. Quarterly Journal of Economics 113: 253-284.

Ashenfelter, O. and C. Rouse. 1999.The Payoff to Education, European Summer Symposium in Labor Economics August 1999. CEPR IZA, Ammersee, Draft.

Becker, G.S., 1964. Human capital:a theoretical and empirical analysis with refeence to education. 2nd edn (Columbia University press New York) NBER.

Card, D., 1999. The causal effect of education on earning In the Handbook for labor economics volume $3 \mathrm{~A}$ Elsevier.

Carneiro, P. 2002. in James J. H. and Xuesong Li, 2003. Selection bias, comparative advantage and heterogenous returns to education: evidence from China National bureau of economic research, Working Paper 9877.

Casapo, M,. 1983. Universal Primary Education in Nigeria: Its Problems and Implications. African Studies Review 26(1): 91-106.

Dabalen, A., 1998. Returns to Education in Kenya and South Africa: Instrumental Variable Estimates. University of California, Berkeley (mimeo). 
Duflo, E., 2001. Schooling and Labor Market Consequences of School Construction in Indonesia: Evidence from an Unusual Policy Experiment. American Economic Review 91(4): 795-813.

Easterly, W., 2001. The Elusive Quest for Growth: Economists' Adventures and Misadventures in the Tropics. MIT Press.

Fafunwa, B.A. 1974 History of Education in Nigeria. London: Allen and Unwin (New edition in 1991).

Federal Office of Statistics (FOS) 1999. Poverty Profile for Nigerians, 1980-1996, FOS: Lagos.

Federal office of statistics. 2000. Annual abstract of statisitcs. Federal office of statistics.

Glewwe, P., 2002. Schooling and skills in developing countries: education policies and socioeconomic outcomes. Journal of Economic Literatue Vol XL, pp436-483.

Glewwe, P.W., 1996. The Relevance of Standard Estimates of Rates of Return to Schooling for Education Policy: A Critical Assessment.Journal of Development Economics.

Griliches, Z., 1977. Estimating the returns to schooling: Some econometrics problem. Econometrica Vol 45.

Haas, M., Sunal, C. , Sunal, D., Rufai, R., Inuwa, A., 2003. Perceptions of Unequal Access to Primary and Secondary Education: Findings from Nigeria" African Studies Review, Apr.

Harmon, C. and Walker, I., 1995. Estimates of the economic returns to education for the united kingdom. American Economic Review 85;1279-1286.

Heckman, J. J., 1979. Sample Selection Bias as a Specification Error. Econometrica 47(1): 153-161.

Hovey, D.C, Knight and J. B, Sabot, R.H., 1992. Is the Rate of Return on Primary Schooling Really 26 Per Cent? Journal of African Economies 1(2):192-205.

Jones, P. 2001. Are educated workers really more productive. Journal of Development Economics 64: 67-79.

Kahyarara, G., Teal, F., Wambugu, A. and Sderbom, M., 2004. The Dynamics of Returns to Education in Kenyan and Tanzanian Manufacturing,Development and Comp Systems, 0409041 Economics Working Paper Archive at WUSTL. 
Kazianga, H. 2002. Schooling Returns for Wage Earners in Burkina Faso: Evidence from the 1994 and 1998 Living Standard Measurement Surveys. Working Paper Economic Growth Center, Yale University.

Lassibille, G. and Tan, J., 2005. The Returns to Education in Rwanda. Journal of African Economies, 14(1):92-116.

Malik, M., 1997. Education and the issue of quality. Education Today, 6 (1), 25-31.

Mincer, J., 1974. Schooling experience and earnings. New York NBER.

Mwabu, G. and P. Schultz, 1996. Education Returns Across Quantiles of the Wage Function: Alternative Explanations for Returns to Education by Race in South Africa. American Economic Association Papers and Proceedings 86(2):335- 339.

Maluccio, J., 1998. Endogeneity of schooling in the wage function: Evidence from the rural Philiphines. Food Consumption Nutrition Divison (FCND) discussion paper No. 54 .

Nielsen, H.S. and Westergard-Nielsen N., 2001. Returns to Schooling in Less Developed Countries: New Evidence from Zambia, Economic Development and Cultural Change January:364-394.

Okojie, C., 2000. Gender and Education as determinant of household poverty in Nigeria. (WIDER) Disc. 2002/37.

Osili, U. and Long, B.T., 2003. Universal Primary education and fertility: A Nigerian Experience. A paper presented at the NEUDC conference 2003.

Ozigi, A., and Ocho, L., 1981. Education in northern Nigeria Winchester, MA:.

Nwachukwu, A.E. 1985. An Historical Analysis of the Roots of Universal Public Primary Education in Nigeria (1900-1980). University of Kansas Ph. D. Unpublished dissertation.

Psacharopoulos, G. and Patrinos, H. A., 2004. Returns to Investment in Education: A Further Update. Education Economics. 12(2): 111 - 134.

Psacharopoulos, G. 1994. Returns to Investment in Education: A Global Update. World Development 22(9): 1325-43.

Schultz, P., 2004. Evidence of Returns to Schooling in Africa from Household Surveys: Monitoring and Restructuring the Market for Education. Journal of African Econ.2004; 13: 95-148. 
Siphambe, H.K., 2000. Rates of Return to Education in Botswana., Economics of Education Review, 19, pp. 291-300.

Staiger, D. and Stock, J., 1997. Instrumental Variable Regression with Weak Instruments. Econometrica 65:557-586.

Tekaligne, G., 1997. Returns to Education in the Manufacturing Sector in Zimbabwe:Some Empirical Evidence. South African Journal of Economics 65(1)99113.

World Bank, 1996. Nigeria - Poverty in the midst of plenty : the challenge of growth with inclusion : A World Bank poverty assessment Document Type: Sector Report.

Uwaifo, R.0., 2006. Three Essays on the returns to Education Enigma in Nigeria. UC Berkeley Unpublished PhD Dissertation.

Zgovu E. and Ephraim W.C., 2000. Does the Return to Schooling Depend on the Type of Employment? Evidence From the Rural Labour Market in Malawi. WP WC/03/01 http://www.geocities.com/echirwa/waco1.htm. 